\title{
SEGMENTY A NÁSTROJE PREDAJA ZÁKAZNÍCKEJ BÁZY FIREMNÝCH ZÁKAZNÍKOV POŠTOVÉHO PODNIKU
}

\author{
Pavol Dydňanskýr ${ }^{1}$ - Radovan Madleňák ${ }^{2}$
}

\section{1. Úvod}

Obchodná stratégia, zákaznícka orientácia a z toho plynúce nastavenie predajných segmentov zákazníckej bázy je kl’účovou úlohou poštového podniku.

Čím kvalitnejšie je zákaznícka báza definovaná, tým je možné presnejšie zameranie predajnej stratégie na dané segmenty. Je potrebné venovat' zvýšené úsilie definovaniu a následnému nastaveniu úloh a ciel'ov pre predajné segmenty zákazníckej bázy. Úlohou predajných zložiek je priebežne sledovat' meniace sa očakávania zákazníkov, trhu, prostredia a následne operatívne upravovat' segmenty zákazníckej bázy.

\section{Poštový trh}

Trhové segmenty sú vel'ké rôznorodé skupiny zákazníkov na trhu. Trhové výklenky predstavujú úzke skupiny zákazníkov so špecifickými potrebami a prianiami.[1] Trh vo všeobecnosti je priestor na uzatváranie obchodov, teda vzniká vždy ked’ obchodujeme.

Trh poštových, finančných a logistických služieb sa v poslednom období významne mení a možno očakávat' ešte dynamickejší vývoj predovšetkým v oblasti elektronických poštových služieb. Penetrácia zákazníkov oproti iným segmentom trhu je relatívne vysoká. Z tohto dôvodu vývoj $\mathrm{v}$ danom segmente služieb pre poštový podnik prináša obrovské ohrozenia ale aj výzvy pre možný budúci potenciál.

\section{Charakteristika firemných zákazníkov poštového podniku.}

Zákaznícka baza firemných zákazníkov poštového podniku je definovaná segmentmi KAM (Key account management), AM (Account management) a SME (Small and medium enterprises), znázornená na obrázku č. 1. Každý segment podniku je špecifický svojimi vlastnost'ami.

\footnotetext{
${ }^{1}$ Ing. Pavol Dydňanský, Slovenská pošta, a.s., Thurzová 1, 04221 Košice, Slovenská republika, tel. č.: +421/55/ 6813 235, e-mail: dydnansky.pavol@slposta.sk

${ }^{2}$ doc. Ing. Radovan Madleňák, PhD., Žilinská univerzita v Žiline, Fakulta Prevádzky a ekonomiky dopravy a spojov, Katedra spojov, Univerzitná 1, 01026 Žilina, tel. č.: 041/513 3129, fax: 041/5655 615, e-mail: radovan.madlenak@fpedas.uniza.sk
} 


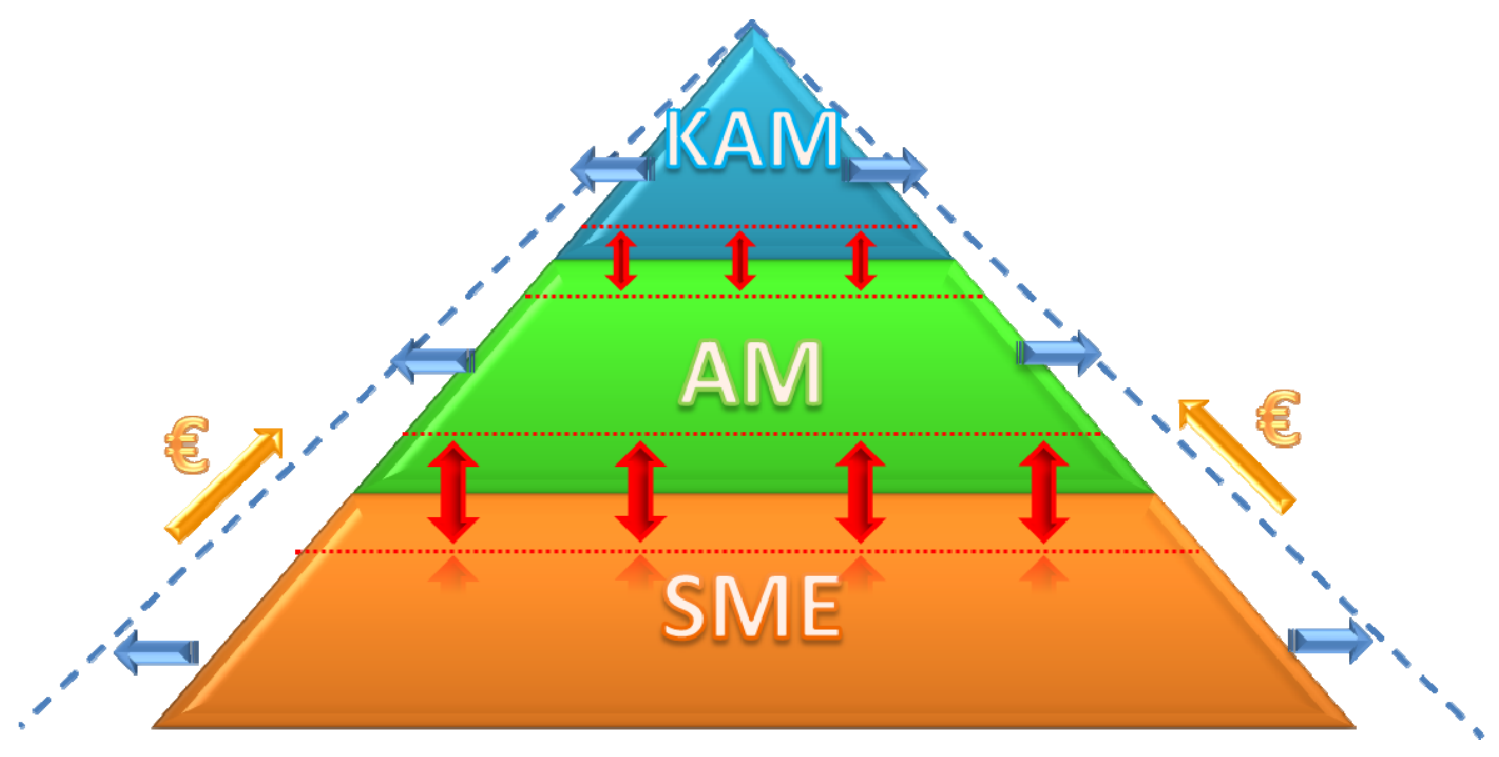

Obrázok č. 1: Zákaznícka báza firemných zákazníkov poštového podniku.

\section{Definovanie segmentov v zákazníckej báze firemných zákazníkov:}

Key account management:

- jedná sa riadenie vzt'ahov kl'účových - strategicky významných zákazníkov poštového podniku. Cielený a systematický rozvoj osobných, pracovných aj mimopracovných vzt’ahov s jednotlivými úrovňami riadenia klúčových zákazníkov. V zákazníckej báze je KAM obchodník definovaný ako špecialista na určitý odbor (štátna správa, verejná správa, priemysel, finančníctvo a bankovníctvo, atd’.), tzv. „ostrel'ovač““.

Account management:

- ide o významných zákazníkov poštového podniku na regionálnej úrovni, úlohou obchodníkov v regiónoch je sledovanie potrieb zákazníkov, vytváranie komplexných riešení - cross selling pre zákazníkov prostredníctvom balíkov služieb, starostlivost' a riešenie požiadaviek segmentu vel'kých a stredných zákazníkov.[2]

Small and medium enterprises:

- ciel'om obchodníkov podniku pre tento segment je obsluha a akvizícia menších zákazníkov na regionálnej úrovni, ktorí v súčasnosti nie sú v starostlivosti spoločnosti a svojím podajom predstavujú zaujímavý potenciál na trhu. Ked’že je predpoklad, že akvizíciou a zvýšenou starostlivost’ou znamenajú potenciálne zaujímavú výnosovú skupinu zákazníkov, je dôležité poskytnút' im osobný kontakt zo strany podniku. V zákazníckej báze má SME obchodník široký záber, podobne ako AM obchodník, teda tzv. „univerzálny vojak“.

\section{Základné princípy fungovania segmentov v zákazníckej báze firemných zákazníkov}

$\mathrm{Na}$ obrázku č. 1, sú znázornené vzt’ahy a prieniky medzi jednotlivými segmentmi zákazníckej bázy firemných zákazníkov poštového podniku. $\mathrm{Na}$ vrchole pyramídy sa nachádza segment klúčových zákazníkov podniku Key account management, po ktorom nasleduje segment významných zákazníkov account management. Pyramída zákazníckej bázy firemných zákazníkov je ukončená segmentom malých a stredných zákazníkov SME.

Princípom zákazníckej bázy je posúvanie významných zákazníkov medzi jednotlivými segmentmi zdola nahor (teda na segmenty kde je zabezpečená individuálna dlhodobá 
starostlivost' o daných zákazníkov) a opačne. Presun zákazníkov zo segmentu SME na segment AM, a zo segmentu AM na segment KAM. Čo znamená, že významný zákazníci pre poštový podnik sú zaradení v starostlivosti podla stanovených kritérí do vybraného segmentu zákazníckej bázy poštového podniku. Pravidelne $\mathrm{v}$ stanovenom období je realizovaná segmentácia zákazníkov, a to presun $\mathrm{z}$ jedného segmentu do segmentu iného. Presun zákazníkov je realizovaný prevažne zo segmentu SME do segmentu AM, resp. zo segmentu AM do segmentu KAM.

\section{Nástroje predaja firemných zákazníkov poštového podniku}

Zákaznícka báza firemných zákazníkov poštového podniku je tvorená predajnými segmentmi, ktoré obsluhujú predajné zložky.

Predajné zložky poštového podniku sú definované dvoma hlavnými činnost'ami:

- starostlivost' o zákazníkov - accounting,

- získanie nových zákazníkov - akvizícia.

Starostlivost' o zákazníkov t.j. accounting, ktorá je dôležitou činnost'ou predajných zložiek poštového podniku. Ide o pravidelnú starostlivost' o zákazníkov v stanovenom segmente, riešenie špeciálnych požiadaviek zákazníkov, teda zastupovanie zákazníka voči podniku a udržanie - retencia, týchto zákazníkov v lieviku predaja.

Snahou predajných zložiek je udržanie zákazníkov, nakol'ko ich neúspech môže mat' za následok odchod ku konkurencii. Na ukončenie obchodného vzt’ahu vplýva množstvo d'alších faktorov ako cenová a produktová konkurencia, kvalita poskytovaných služieb, atd'. Hlavným ciel'om je zabezpečit', aby $\mathrm{z}$ poštového podniku odišiel minimálny počet zákazníkov. Ďalšou úlohou predajných zložiek je realizácia up-selling a cross-selling, v segmente zákazníkov. Týmto spôsobom dochádza k rozširovaniu zákazníckej bázy firemných zákazníkov.

Inou úlohou predajných zložiek poštového podniku je aktívne získavanie nových zákazníkov - akvizícia, resp. hunting. Jedná sa o aktívne vyhl'adávanie potenciálnych zákazníkov pre poštový podnik. Vyhl'adávanie skrytých príležitostí je vel'mi dôležité, a to aj z dôvodu, že penetrácia zákazníkov medzi poštovými podnikmi je vysoká.

Jednou z možností pri vyhl'adávaní predajných príležitostí je orientácia poštového podniku na zahraničných zákazníkov. Ide o zákazníkov mimo územia krajiny, kde je potenciál obrovský. Podstatné sú v takomto prípade rôzne obmedzenia (technologické, logistické, legislatívne, atd'.), respektíve neželaná konkurencia medzi poštovými správami.

Znovu získanie zákazníkov (win-back), ktorí ukončili spoluprácu s poštovým podnikom je rovnako dobrou predajnou príležitost'ou pre získanie dodatočných výnosov a zvýšenie predaja. Výhodou v tomto segmente zákazníkov je história komunikácie a poznanie dôvodu ukončenia obchodného vzt'ahu.

Strata zákazníkov zo zákazníckej bázy, vedie $\mathrm{k}$ poklesu výnosov, čo môže byt' efektívne nahradené akvizíciou nových zákazníkov. Obe činnosti predajných zložiek sú nevyhnutnou súčast'ou lievika predaja, ktoré sa navzájom dopíňajú, nie je teda žiaduce sa spoliehat' len na jednu predajnú činnost'.[4]

\section{Záver}

Zákaznícku bázu poštového podniku tvoria segmenty firemných zákazníkov. Nástrojom predaja sú predajné zložky, ktorých úlohou je retencia, teda udržanie zákazníkov v poštovom podniku, ale aj akvizícia nových zákazníkov. Presuny firemných zákazníkov medzi segmentmi je realizovaný pre stanovené obdobie na základe vhodne zvolených kritérií. Manažéri predajných segmentov týmto zabezpečujú optimalizáciu zákazníckej bázy, efektívne fungovanie zákazníckych segmentov, čím sa dosahuje finančný prínos pre poštový podnik. 


\section{Literatúra}

[1] KOTLER, P. Marketing management. 10 rozš. vyd. Grada publishing, spol. s r.o., 2001. 279 s. ISBN 80-247-0016-6.

[2] DYDŇANSKÝ, P. Zákazníkovi chceme poradit', ako sa orientovat' v portfóliu našich služieb. 2009. [online]. Poštové zvesti pre firmy, ročník II., 3/2009 [cit. 2012-4-12]. Dostupné na internete: <http://www.posta.sk/subory/826/postove-zvesti-pre-firmyc32009.pdf $>$.

[3] LAMBERT, B. 10 Steps to Successful Sales. Alexandria, Virginia : ASTD Press, 2010. 247 s. ISBN 978-1-56286-686-0.

[4] DYDŇANSKÝ, P. - MADLEŇÁK, R. Integrovanie predajno marketingových nástrojov v lieviku predajných príležitostí poštového podniku. In: IPoCC - International Postal and e-Communications Conference: sborník př́spěvků mezinárodní konference IPoCC "Možnosti rozvoje poštovních služeb a elektronických komunikací" = proceedings of the IPoCC Conference "Possibilities of Postal Services and e-Communications Development" : Pardubice , September 13th-14th, 2012. - [Pardubice]: Institut Jana Pernera, 2012. - ISBN 978-80-86530-84-0.

[5] MADLEŇÁKOVÁ, L. : Metodika hodnotenia a stanovenia optimálnej ponuky poštových služieb, In: Doprava a spoje [elektronický zdroj] : internetový časopis. - ISSN 1336-7676. - 2011. - Č. 1 (2011), s. 67-70.

\section{Grantová podpora}

IV 6/KS/2012 Optimalizácia poštových technologických procesov vo väzbe na dopravný systém

VEGA 1/0421/12 Modelovanie difúzie znalostí v podnikových hodnotových ret’azcoch 